\title{
The impact of think pair share model on mathematics learning in elementary schools
}

\author{
Shila Majid Ardiyani, Gunarhadi, Riyadi \\ Department of Elementary School Teacher Education, Sebelas Maret University, Indonesia
}

\begin{tabular}{l}
\hline \hline Article Info \\
\hline Article history: \\
Received Feb 15, 2018 \\
Revised Aug 25, 2018 \\
Accepted Nov 23, 2018 \\
\hline
\end{tabular}

\section{Keywords:}

Cooperative learning

Mathematics learning

Think pair share

\begin{abstract}
One objective of mathematics learning is to solve problem and to communicate idea to get a solution. Human life is inseparable from social activity, including cooperation. Similarly, in mathematics learning sometimes students need friends to discuss with in solving mathematics problem. Cooperative learning model can be an alternative to bridge the difficulty the students encounter. The objective of research was to identify the impact of Think Pair Share type of Cooperative learning model on mathematics learning in elementary school. This study was a descriptive qualitative research. The subject of research was the fifth graders of three elementary schools in Karangpandan Sub District. Techniques of collecting data used were observation, interview, and documentation. Observation was conducted to observe the learning process using Think Pair Share-type of cooperative learning, interview to find out the impression and the impact the students experience, and documentation to find out the group's work. The conclusion of research showed that there are some impacts found in mathematics learning using Think Pair Share type of cooperative learning related to: (1) group establishment; (2) learning environment; (3) learning achievement; (4) student participation; (5) information exchange; and (6) interpersonal relation.
\end{abstract}

Copyright (C) 2019 Institute of Advanced Engineering and Science. All rights reserved.

\section{Corresponding Author:}

Shila Majid Ardiyani,

Department of Elementary School Teacher Education,

Universitas Sebelas Maret,

Ir. Sutami Street 36A, Surakarta 57126, Indonesia.

Email: shilafanila@gmail.com

\section{INTRODUCTION}

Mathematics contributes to help solve daily problems and to support science and technology development. It is in line with the objective of mathematics learning, according to Permendiknas No.22 of 2006, among others to solve problem and to communicate idea using symbol, table, chart, or other media to clarify a condition or a problem [1]. Basic skill in mathematics learning, according to Kumar and Rao, is "....to help children learn to solve problem, to communicate mathematically and to demonstrate reasoning abilities" [2].

Human beings need cooperation between one and another for the sake of their life sustainability. Learning is a social process needing interaction between teacher and student, and between students. Cooperative learning model is evaluated corresponding to the learning concept itself. This model is developed based on social constructivism theory held on by Vigotsky, emphasizing on the socio-cultural essence for the higher function through interpersonal relation [3]. Cooperative learning is characterized with the cooperation in group consisting of students with heterogeneous ability and background. Cooperative learning, according to Eggen and Kauchak, is teaching strategy emphasizing on the interaction between students [4]. It means that every student plays a more specific role compared the usual group work or individual work does. 
Think Pair Share model was introduced for the first time by Frank Lyman in 1985. Think Pair Share, according to Tint and Nyunt, is an activity that can encourage the students to reflect on the problem and then to share idea with others, in which other's idea can be used to develop their own ability [5]. So, the students are required to think independently first and then to discuss with their tablemates. Its implementation starts with the teaching giving problem, and then the students think of the solution individually (think), discuss in pair (pair), and ends with class discussion (share). TPS has been recommended for its advantage of enabling the students to express their reasoning, reflecting the way they think, and obtaining direct feedback to their understanding.

Slavin said that educational research is mostly often conducted to find out the impact of cooperative learning on the students' learning achievement [6]. Gull's study concluded that the activity in cooperative learning affects positively the academic achievement of students [7]. Meanwhile, the research related to Think Pair Share type of cooperative learning conducted by Kothiyal et al. found that $83 \%$ of students participate in the implementation of Think Pair Share [8]. In addition, Marta's study found that Think Pair Share model can improve learning achievement, self-confidence, and self-esteem, and can find out the students' ability [9]. It indicates that Think Pair Share model allows the impactive discussion learning process and can improve the students' participation.

This implementation of Think Pair Share model is conducted because many students still find difficulty in solving mathematics problems and their learning outcome completeness is still low. Many findings of study have elaborated the advantages of Think Pair Share model, but only few studies discuss the impact of this model application. For that reason, this research tries to complete previous research, by means of elaborating think pair share type of cooperative learning model in mathematics learning of elementary school. The objective of research was to identify the impact of Think Pair Share type of cooperative learning model in mathematics learning of elementary school.

\section{RESEARCH METHOD}

This study was a descriptive qualitative research. The subject of research includes the fifth graders of three elementary schools in Karanganyar, Central Java, Indonesia. Techniques of collecting data used were interview, observation, and documentation. Interview was conducted to explore information from teacher and students. Observation was conducted to find out the implementation of mathematics learning in class, and document study was conducted to find out the mathematics learning outcome of students. Technique of analyzing data used in this research was an interactive model of data analysis according to Miles \& Huberman consisting of data collection, data reduction, and data display, and conclusion drawing/verification [10].

\section{RESULTS AND DISCUSSION}

The result of research shows that there are some impacts of Think Pair Share type of cooperative learning model on mathematics learning related to: Group establishment, learning environment, learning achievement, student participation, information exchange and interpersonal relation. The explanation about the Think Pair Share type of cooperative learning model is explained as follows.

\subsection{Group establishment}

Each of group established in Think Pair Share model consists of two members or called pair. Group establishment is very impactive and can save time, as suggested by Lie that the group establishment in TPS is easier and quicker [11]. The negative impact results when the number of students in a class is odd, thereby one of groups consists of 3 members. The observation on the group consisting of 3 member's shows that discussion runs less impactively, as some students work on mathematics problem actively, and some others tend to be passive. In addition, when the number of students in a class is large, so is the number of group established. This requires the teacher to work extra hard in monitoring the student discussion, as the groups often report or ask question when they find difficulty.

Regarding the solution, teacher should be able to conduct class management well. Without class management making the students disciplined, the learning circumstance becomes less conducive. When the number of groups is too large, additional teachers are needed to help the main teacher, because one teacher cannot monitor each of groups continuously. Chauhan said that in cooperative learning, teacher serves as guide, stimulator, and supporter, rather than the one sharing information [12].

Additionally, during group establishment, some groups are found still homogeneous, in which a group has members with equal ability; actually it will not be the problem when all of members are clever, but when all of them are less clever, it can inhibit the discussion process. During discussion, students are required 
to respond quickly to any problem the teacher assigns. This group tends to experience many difficulties during working on mathematics problem. As a result, when other groups have worked on the problem completely, this group has not yet thereby using the time up. From the result of documentation on the student discussion about factoring, some groups have members who have not understood division concept so that both of them find difficulty and cannot solve the problem well. The heterogeneous group is established more easily, when in one group there are 4-5 members. Thus, teachers should pay more attention to the establishment of group in Think Pair Share model.

Aziz and Hossain, cooperative learning model requires heterogeneous group in the term of intellectual ability, academic interest, and cognitive style to improve the relationship between students with high ability and those with low ability [13]. Ventimiglia said that cooperative learning requires the instructor to pay attention to group establishment, group composition, group dynamic, student work assessment, and group assignment design [14]. Confirming this, Roger \& Johnson stated that teacher should also consider school cooperation, for example, by means of holding a weekly meeting with 2-5 teachers and discussing the way of implementing cooperative learning more impactively in their classroom [15]. So, not only students but also teachers can cooperate with others.

\subsection{Learning environment}

During discussion process, the clever students are more dominant and some of them are individualistic during working on the complicated mathematics problem, while the students considered as less capable underperforming in mathematics tend to be ignored. It results in gap (discrepancy), in which one active student and another is passive. From the result of observation, it can be seen that the dominant students tend to work individually regardless their discussion friend's opinion or input. Meanwhile, individualistic students prefer working on the mathematics problem independently to sharing it in group discussion. It is likely because they are accustomed with and more confident when working on the problem alone (conventional model) and feel less comfortable to share their thinking with others. It is confirmed with the result of interview with a student stating "I do not like to discuss in group, as my group friend do not think much, but I do."

When cooperative learning is not well-designed, according to Slavin, it will result in "free rider" or "pillion" in which there is a member of group working on all or most of work, while another one only ride on it [16]. It is also found in the implementation of Think Pair Share. The clever student tends to take over most of group work for the sake of easiness and quickness rather than to help his/her less clever friend or the one finding difficulty. Otherwise, the less clever student tends to rely on the clever or diligent one for completing their group work. It results in uneven task or workload distribution and makes the less clever students retarded.

It is because, among others, the students are always accustomed with competitive conventional learning, thereby leading to individualism. Johnson \& Johnson stated that in individualistic learning environment, the achievement of students' objective is independent [17]. Individualistic learning environment refers to a strategy in which the students work individual for achieving their own objective. In line with this, Roger \& David stated that they can compete with others to see who is 'the best' and can work individualistically to achieve their objective regardless other students, or they can cooperate with their own equally good learning interest [15]. Parrenas stated that the principle to encourage the successful cooperative learning is to distribute students' leadership, to establish group heterogeneously, to facilitate social skill acquisition, and to enable group autonomy [18]. The success of Think Pair Share is supported by a conducive learning environment by minimizing individualist attitude and observing group heterogeneity.

\subsection{Learning achievement}

The implementation of Think Pair Share shows that the students' achievement improves, compared with their previous achievement in pretest, and so does the learning completion. The pretest completeness is only $12 \%$ whereas after the research increased to $38 \%$. It is in line with Martha's study concluding that the students taught using Think Pair Share learning model have higher achievement than those taught using conventional method [9]. Kothiyal states that TPS has been recommended for its advantages of enabling the students to express their reasoning, to complete and to think of it, and to get feedback immediately to their understanding [8]. The students express their opinion more freely and get feedback from their group friend. For the optimum result, Johnson \& Johnson recognizes the need for integrating cooperative learning and competitive individual learning [17]. The competitive learning intended here is the one in intergroup context in order to motivate the students to work well in their group for the sake of mutual objective. Parrenas and Parrenas suggested that cooperative learning facilitates the students to have higher learning achievement [18]. 


\subsection{Student participation}

Student participation is very visible because previously the students were accustomed with conventional learning emphasizing on individual ability, rather than cooperation. Student participation improves in the learning with Think Pair Share Model, particularly in "pair" and "share" stages. In "pair" stage, students discuss in pair and then in "share" stage, they discuss with their classmates. When a group is presenting their work before the class, other groups listen to them; when there is dissenting opinion, they can ask question, give recommendation, or justify the answer. Lie said that Think Pair Share can improve the student participation in expressing their thinking discretionarily [11]. Student participation in Think Pair Share, according to Kothiyal, reaches $83 \%$ out of total average students [8]. Kagan and Kagan mentioned that this interaction can improve the number of students participating actively at a moment and the frequency of individual students' active participation [19].

Appreciation (reward) is very important in cooperative learning. Morgan suggested that students will be committed to participate in a team when they are rewarded for that participation, and vice versa [20]. Dyson \& Grineski stated that cooperation emphasizing on the need for individual students' contribution to achieving mutual objective can affect very positively the students' learning [21]. It is confirmed by Ejiwale stating that cooperative learning successfully enabling the students to have opportunity of interacting and cooperating with their peer and being responsible for an assignment [22]. Think Pair Share allows students to contribute actively in group discussions.

\subsection{Information Exchange}

Information exchange will be more diverse when the number of members is adequate and heterogeneous. Think Pair Share group only has two members, thereby results in limited information exchange and limited idea emerging. It is confirmed by students stating that they find difficulty when working on a difficult problem and no one in group can work on it. The limited information exchange precludes the students from working on the difficult problem. As a result, the discussion can be inhibited. It is in line with Lie stating that one disadvantage of Think Pair Share model is that only few ideas emerge[11]. However, Kothiyal said that Think Pair Share enable the students to express their reasoning or idea and getting direct feedback to their understanding [8]. Information exchange also occurs in the stage after working individually for an answer (think), as suggested by Li \& Lam that when the students in pair and share their view on the question until they reach a consensus about the answer, and in "share" stage, a half of class practices speaking skill, while another practices listening skill [23]. The feedback occurring in class discussion can improve intergroup information exchange as well.

\subsection{Interpersonal relation}

Interpersonal relation is getting better when the students discuss to solve the problem in pair and discuss with the class. The students learn to appreciate the difference and the diversity existing. It can be seen from the students formerly still facing other opposite-sex members of groups shyly now beginning to adapt to and to try solving the problem in pair. Kohn suggests that working in the team in class will encourage flexibility and adaptability and inclusive interpersonal relation [24]. Think Pair Share, according to Eggen and Kauchak, can reduce the "free rider" tendency impactively as it consists of only 2 members [4]. The limited number of "free rider" can encourage a better interpersonal relation. It is confirmed by Kolewole stating that it is intended to create interdependency in positive term by means of encouraging all members of group to contribute to discussion and to discuss the result of discussion [25]. Othman, et al confirmed that the students' maturity can be created as the result of cooperative learning experience, particularly the positive social skill, such as interpersonal relation [26].

\section{CONCLUSION}

This research elaborates the impact of Think Pair Share type of cooperative learning model on mathematics learning in elementary school. Think Pair Share type of cooperative learning model affects positively but it also affects negatively related to: Group establishment, learning environment, learning achievement, student participation, information exchange and interpersonal relation. This research is expected to give understanding on the impact of think pair share type of cooperative learning thereby helping the teacher or the author design a more meaningful and impactive teaching strategy and anticipate the negative impact likely occurring. The students need to learn working harmoniously with other students in group and individually, and integrating both of them. This research concludes that cooperation between teachers, between students, and between teacher and student can minimize the negative impact and can impact on the successful cooperative learning. The research has limitation as it involves only 3 elementary schools and uses only one of various cooperative learning models, Think Pair Share. Therefore, further 
studies on the impact of cooperative learning model need to be conducted with broader population or with other types.

\section{ACKNOWLEDGEMENTS}

I would like to thank to my consultant lecturer in Sebelas Maret University of Surakarta for guiding me in completing this thesis and article writing. I also would like to thank to all of those participating in this research, particularly teachers and the fifth graders of elementary schools in Karangpandan Sub District.

\section{REFERENCES}

[1] Depdiknas, " Permendiknas (Minister of National Education Regulation) No. 22, 2006, stats about the standar isi for elementary and high school levels (in Bahasa)," ed Jakarta: Depdiknas, 2006.

[2] S. J. V. Kumar and D. B. Rao, Techniques of teaching mathematics, New Delhi: Sonali Publications, 2006.

[3] L. S. Vygotsky, Thought and language, USA: Massachusetts Institute of Technology, 1986.

[4] Eggen, P. and Kauchak, D., Strategies and Models for Teachers: Teaching Content and Thinking Skills (in Bahasa), Jakarta: PT Indeks, 2012.

[5] Tint, S. S., and Nyunt, E. E., "Collaborative learning with think -pair - share technique," Computer Applications: An International Journal (CAIJ), vol.2, pp. 1-11, 2015.

[6] Slavin, R. E, "Research on cooperative learning and achievement: what we know, what we need to know," Contemporary Educational Psychology, vol.21, pp. 43-69, 1996.

[7] Gull, F., "Effect of cooperative learning on students' academic achievement," Journal of Education and Learning, vol. 9, pp. 246-255, 2015.

[8] Kothiyal, A., et-al, "Effect of think-pair-share in a large CS1 class : $83 \%$ sustained engagement," International Computing Education Research (ICER), vol. 13, pp. 1-8, 2013.

[9] Martha, M., Prof, I. E., and Seraphina, M. (n.d.), "Effect of think-pair-share strategy on secondary school mathematics students' achievement and academic self-esteem in fractions," American International Journal of Contemporary Scientific Research, vol. 2, pp. 141-147. 2015.

[10] Miles, M.B. and Huberman, A.M, Qualitative data analysis, London: Sage Publishers, 1994.

[11] Lie, A, "Cooperative Learning," Jakarta: Grasindo, 2002.

[12] Chauhan, MS. S., "Cooperative learning versus competitive learning: which is better?," International Journal of Multidisciplinary Research, vol. 2, pp. 358-364, 2012.

[13] Aziz, Z., and Hossain, M. A, "A comparison of cooperative learning and conventional teaching on student's achievement in secondary mathematics," Procedia - Social and Behavioral Sciences, vol. 9, pp. 53-62, 2010.

[14] Ventigmiglia, L., "Cooperative learning at the college level," Thought and Action, vol. 9, pp. 5-30, 1994.

[15] Roger T. and David W. Johnson, "An overview of cooperative learning," online, 2002.

[16] Slavin, R. E., Cooperative learning: teori, riset dan praktik, Bandung: Nusa Media, 2005.

[17] Johnson, D. W. and Johnson, R. T, "Cooperative, competitive, and individualistic learning", Journal of Research and Development in Education, vol. 12,pp. 3-15, 1978.

[18] David W. Johnson and Roger T. Johnson, "Making cooperative learning work," Building Community through Cooperative Learning, vol. 38, pp. 67-73, 1999.

[19] Kagan, S. and Kagan, M., Kagan cooperative learning, San Clemente: Kagan Publishing, 1994.

[20] Morgan B., "Cooperative learning in higher education: Undergraduate student reflections on group examinations for group grades," College Student Journal, vol. 37, pp. 40-50, 2003.

[21] Dyson B., and Grineski S., "Using cooperative learning structures in physical education," Journal of Physical Education, Recreation, and Dance, vol. 72, pp. 28-31, 2001.

[22] Ejiwale J., "Barriers to successful implementation of STEM education," Journal of Education and Learning, vol. 7, pp. 63-74, 2013.

[23] Li, M. P. and Lam B. H., Cooperative learning, Hong Kong: Education of Hong Kong Institute, 2005.

[24] Kohn, A., "Resistance to cooperative learning: Making sense of it deletion and dilution," Journal of Education, vol.174, pp. 38-56, 1992.

[25] Kolawole, E. B., "Effects of competitive and cooperative learning strategies on academic performance of Nigerian students in mathematics," Educational Research and Review, vol. 3, pp. 033-037, 2008.

[26] Othman, H., et-al, "Students' Perceptions on Benefits Gained from Cooperative Learning Experiences in Engineering Mathematics Courses." Procedia - Social and Behavioral Sciences, vol. 60, pp. 500-506, 2012. 